\title{
The Implementation of Article 29 UUD 1945 as an Embodiment of Religious Tolerance in Indonesia: An Islamic Law Perspective
}

\author{
Oheo K. Haris, Muh. Yazid \\ Faculty of Law, Haluleo University, Kendari \\ Email: oheokh@gmail.com
}

\begin{abstract}
This article discusses the implementation of article 29 UUD 1945 as an embodiment of religious tolerance in Islamic law perspective. Religious tolerance has become an essential object, this because of pluralism cultures and various religions which have been naturally developed as well as accepted by all of the citizens. If this could not well-managed in an atmosphere of good cooperation, then it is possible that differences in religious culture would have trigger social conflict. The findings suggest on that article provision on 29 Indonesian Constitution contained; (a) Believing and god-fearing on Oneness God in accordance with human civilized; (b) Construct the respect and tolerance among religions; (c) Admitting that every citizen free to worship and not to impose the will on other people's religion. This respect is merely to look for and find out the similarity and equality that may have advantages as comparative materials.
\end{abstract}

Keywords: Religious, Tolerance, Social Conflict, Equality

\section{Introduction}

One of the factors for the formed unity and integrity is actually built by an embodiment of among religious tolerances. In spite of different believing, this statement is obviously considered as 
given freedom and independence for each citizen in order to believe on and worship their each religion ${ }^{1}$.

In Indonesia, religious tolerance has become an essential object, this because of pluralism cultures and various religions which have been naturally developed as well as accepted by all of the citizens. If this could not well-managed in an atmosphere of good cooperation, then it is possible that differences in religious culture would have trigger social conflict.

Therefore, in order to keep unity and integrity, the existence of tolerance ought to be a pivotal moment. According to Humaidi "if there is disagreement in a case such as religion, ideology, politics, etc., that should not be a reason to hold a dividing line in daily interaction". One thing that could not be hiding in the history human interaction was concerning about the difficulties of unity and integrity among religious in which this difficulty usually caused by either contiguity or misperception. Thus, those matters automatically ignore such a harmony between one and other religions. In fact, in the name of religion, it would prompt a civil war due to misperception by religion itself. Ibnu Taimiyah pointed out that all of the religions are the same namely the Islam, so that the value of religion should be well-kept and must not stray far from the objectives and order of religion itself, which is human living peacefully ${ }^{2}$.

Discourse above, need to be understood and enhanced about the concept of tolerance that more transparency and this

${ }^{1}$ Guidelines of The Pancasila and Indonesian Constitution 1945, DECREE of INDONESIAN CONSULTATIVE ASSEMBLY (MPR), (Pedoman Penghayatan dan Pengamalan Pancasila dan UUD 1945), GBHN TAP MPR No.II/MPR/1988. BP7. PUSAT, 1990, p. 7

2 Nurcholis Madjid, Pro-Contra Towards 1995 (Pro-Kontra Menuju Tahun 1995), Paramadina Press, Jakarta, 2005, p. 2 
requirement was well-founded because the implementation of religious tolerance currently is not applied well. Besides, the concept also is being the quasi horizon. As a small-noticed that Arswendo's case showed that the Prophet Muhammad S.A.W was placed in improper level, Sampang case in Madura Island, Tasikmalaya case and many more attracted such an international attention was the case of Tribe case Religion, Race, and the Inter-group (here refer to SARA) that happened in Ambon Province. Unfortunately, those cases were solved by political matters without attending to the real of religious values and whether this case was solvable.

In order to resolve this problem, it is called for a taking dialogue seriously as well as a long process among religious leaders who to aim and foster harmony and unity, not to seek a point equation but rather to spread the truth. This is mentioned a surah/Koran Ali Imran: 64;

Say, "O People of the Scripture, come to a word that is equitable between us and you - that we will not worship except Allah and not associate anything with Him and not take one another as lords instead of Allah." But if they turn away, then say, "Bear witness that we are Muslims [submitting to Him]."

In respect of statement above can be seen as a religious phenomenon that commonly occurs in social life. However, this phenomenon was not merely considered and understood by an essential solution in order to form a secure, peaceful and disagreement that might disastrously for the citizen. While it is known that marked differences continuously arise and cannot be decided whether the disparity would end. Like a wise man said, "we must have a unity in diversity". This conception meant that the harmonization is principally demanding a basic foundation and needing some input for each religion in order to construct the harmony and integrating a mission and vision of the development of human civilization. 


\section{MATERIALS AND METHOD}

The method used in the present study is divided into type of study and problem approach. Type of study refers to legal research. The legal study characteristic is to discover pragmatic truth where its truth is based on the congruence between the examined truth and imposed rules. Peter Mahmud Marzuki ${ }^{3}$ stated that legal research is a process to find out the rule of law, law principles, and law doctrines in order to solve an existing legal problem. It is in line with the prescriptive character of legal studies. He further said that problem approach, according to the theory of Peter, is a study using several approaches as whole unities, which are statute approach, case approach, and conceptual approach.

This work was compiling with several analysis as follow;

1. Research method is the empirical research which emphasized through literature study and major references were to analyze the interpretation of Koran, Hadith, and Fiqh. This data which used was data's result of development of Islamic law by means of base line system. In addition, the materials collected to mainly examine the implementation of article 29 of Indonesian Constitution both by Islamic scholar thoughts and Islamic Law

2. This work has worked by religious tolerance approach, which used by literature study over the Islamic rules and documents related and field research in order to get a solution related to openness, acceptance, and tolerance in actualizing and creating broad-mindedness.

3 Peter Mahmud Marzuki, Legal Research (Penelitian Hukum), Edisi Revisi, Cetakan ke-8, Publisher Kencana Prenada Media Group, Jakarta, 2013, h.30 


\section{Findings}

In Islamic tradition, tolerance has formed the rules that must be caressingly remarked special for non-Muslim. It is here asserted that the rules basically were part of the principle of Islamic fundament which based on Koran. One could have to take advantages, rights, and peculiarities. He or she truly free from internal religion matters, rites, rituals, rules, and personal behavior. They externally should be protected and defended that lead to implementing the rules, for example, general rules toward the social problem, external relation, and public protection. Due to the inner belief of internal and external, on one hand, he or she has the right to favor Muslim as long as not paradoxically against legal personal. On other hand, nonMuslim has passively to act that hence to favor the cost of action.

A freedom of life and conscience for non-Muslim ought to be guaranteed that commonly known as dhimmi it refers to a person who has obligation to pay $\operatorname{tax}^{4}$. It is here asserted that The Prophet Muhammad said: Who are the Muslims who killed the dhimmi (people who pay tax), then he or she would not have the slightest chance the chance to get the smell of paradise, protect them because they are my dhimmi.

Globalization upon Islam must show that the struggle for human dignity and social justice should base on the Authority and Sovereignty of Allah SWT. The successful of transformation has demanded the absence of special rights particularly the person who has authority. In order to generally implement Islamic tolerance, it is not about concerning the distribution of income as well as opportunity fairness and

\footnotetext{
${ }^{4}$ Umar Faruq Thohir, Discourses of the Rights of Minority of Kafir Dzimmi in Muslim Majority, (Diskursus Tentang Hak Asasi Minoritas Dzimmi Di Tengah Mayoritas Muslim), Article, 2002, p.2.
} 
balance, but also the more significant is ability and responsibility. The process should reconstitute special rights and authority for a dominant level to address the poor. Religious leaders, social, economics, civil, politicians have should not distribute, but more delegated to a small group that would obtain advantages and provide sanctions. The goal of transformation is to establish power and reanimate justice and eventually reconstructed sovereignty of Allah Almighty.

\section{DISCUSSION}

\section{Openness as Gesture towards Religious Tolerance in Indonesia}

A Tolerance in Arabic term can be defined as Tasamub which meant to have sincerity in social intercourse. The word of Tasamuh is also determined as Tasahul which meant to make easier. According to webmaster's new American Dictionary (2001:1050) explains tolerance as liberality toward the opinion of others, patience with other. This meant that to give liberty toward one's opinion and to face one's perception patiently.

The distinctions in religion have become a necessity that normally created a mutually beneficial cooperation and formed appreciation the appearance of a nation. In reality, sometimes, people act just as a man of God to justify his or her own opinions and blame other people's opinion. Whereas Allah Almighty never show the appearance's one, but merely has given what trait or characteristics of person ${ }^{5}$.

${ }^{5}$ Umar Hasyim, A Tolerance and Religious Freedom on Islam as a Basic Dialog and Harmony among Religion (Toleransi dan Kemerdekaan Beragama dalam Islam Sebagai Dasar Menuju Dialog dan Kerukunan Antar Agama), Publisher PT. Bina Ilmu, Surabaya, 1979, p. 22. 
Figuring out tolerance in Islamic Law can be dealt with as follow;

1. Holy Koran, this guide was primarily the first which contained a major rule and need to be further analyzed and developed. Syaid Husein Nasar pointed out that Holy Koran has a three main fundamental objects; (a) Koran scientifically contained real of natural composition and various creature position in universe in which there are consisted of faithful, laws, and morality.

(b) Koran covered a guidance that resemble history of mankind, citizenry, kings, holy people, along with prophets and other temptation that befell them. (c) Koran comprised a difficult language explanation because its came from Word of God which has different power towards what we learn nationally ${ }^{6}$.

2. Assunnah atau Al-Hadist/ Hadith, which implemented after Koran that contained words, deeds, attitudes of Prophet Muhammad SAW that stated on Hadith Books, interpreted, and authentically Koran description. By means of this hadith, one could recognize his or her Prophet and mission of Koran that usually applied for life guidance

3. Ijtihad ${ }^{7}$ or personal examination, this effort was the third basic of Islamic Law that considered as individual

6 Muhammad Daud Ali, Islamic Law (Hukum Islam), Published by Raja Grafindo Persada, Jakarta, 2001, p. 66

7 In Islamic law that the use of reason to arrive at a knowledge of truth in religious matters. Is an Islamic legal term that means "independent reasoning" or "the utmost effort an individual can put forth in an activity?" It is recognized as the decision-making process in Islamic law (sharia) through personal effort (jihad) which is completely independent of any school (madhhab) of jurisprudence (Fiqh). As opposed to taqlid, it requires a "thorough knowledge of theology, revealed texts and legal theory (usual al-Fiqh); an exceptional capacity for legal reasoning; thorough knowledge of Arabic." By using both the Qur' an and Hadith as resources, the scholar is required to carefully 
interpretation and judgment that also must have a prerequisite for struggling, endeavor, and all of effort in order to understand legal fundamental norms which stated in the Koran.

Legal norm has a general character that specified in the As Sunnah and formulated as universal rules, and tries to deal with that not defined in either the Koran or As Sunnah.

Description above showed that Islam as religions that has individual system as well as incorporate part which likewise has one aim. The resource was unity of God then called as faith. From the faith will follow sharia and Islamic moral and both the two component were put in order a deed and attitude in social interaction. The third of those compositions has become basic Islamic thoughts which developed by means of Islamic systems such as Islamic philosophy system, education, culture etc.

The implementation of openness in Islam cannot be separated from a fair attitude towards other religion. Beforehand, it is important to understand the meaning of fair and its essence. The word of fair was coming from Arabic language which meant the same. In Bahasa called equal weight, not biased, impartial, siding with right, hold on to the truth and duly. Thereby, someone called to be fair if he or she is not partial in any judgment unless he or she's impartiality to whom the right person so then that he or she will not apply arbitrary.

Concerning fair, due attention, has seriously become main topic among Muslim scholars. One of them was Quraish Shihab who

rely on analogical reasoning to find a solution to a legal problem, which is considered to be a religious duty for those qualified to conduct it. Thus, a mujtahid is recognized as an Islamic scholar who is competent in interpreting sharia by ijtihad. Today, there are many different opinions surrounding role of ijtihad in modern society. 
discussed the order of justice enforcement in the Koran which quoted the three main points namely Al-Adl, Al-Qisth, and AlMizan. The word of Al-Adl, according to him, was the same that impressible for two or more group, and Al-Qist showed a part of proper and worth, and the last was Al-Mizan which exposed to a tool of consideration that meant fairness. Although the three have different meaning, but have the same goal namely a command to be fairness.

Yusuf Qardlawi ${ }^{8}$, other scholar, emphasized the meaning of fair was to deservedly contribute to the right's one either personally or group with any kind of value without beyond and reduced. It is here asserted that the rights of person noticeably cannot be reduced and arbitrated upon another's rights. Koran said that;

O you who have believed, be persistently standing firm for Allah, witnesses in justice, and do not let the hatred of a people prevent you from being just. Be just; that is nearer to righteousness. And fear Allah; indeed, Allah is acquainted with what you do.

Interpretation above is able to show that the enmity and hate then triggering to treat injustice towards other group. Therefore, we could give the right for withesseth or testimonial whatever be heard with the rights that they would deservedly accepted. Besides, we should also consider by an appropriate decision, because the Believers (Mukmin) considered most important the justice rather than to tyrannically execute and imbalance to them. The justice must be placed over lust, personal interest, enmity, and any kind of subjective attention. Next interpretation was supporting the previous sentence, it is important to note that the fairness was very crucial and obligated that must be enforced just because the fairness was

8 Yusuf Qardlawi, an Islamic Social System in the Koran and Sunnah (Sistem Masyarakat Islam Dalam Al-Qur'an \& Sunnah), Published by Pustaka Online Media ISNET, Pakdenono, 2006, p. 115. 
most closely to God-fearing and out of His evilness. It is here asserted that God's desire has become magnificence and would not have His comparison?

\section{Acceptance of Latitudinarian and Pluralism in Islam}

The acceptance, in Islam perspective, was defined as the core as well as the understanding of latitudinarian and pluralism. It is here asserted that Koran Al-Baqarah: 148 said;

: For each (religious following) is a direction toward which it faces. So the race to (all that is) good. Wherever you may be, Allah will bring you forth (for judgment) altogether. Indeed, Allab is over all things competent.

Every single community expected to accept a diversity of social cultures and tolerance among religion that continuously openhanded a freedom and opportunity for everyone to go through a period of one's life and to perform a religious obligation. What is desired in living civilization is every plural group of society that they competed against each other fairly and properly. It is here declared that Allah Almighty knows about good and bad and right-wrong. The current expectation, in Indonesia, is clearly enough. The existing of religious variety in Indonesia historically initially from Soekarno's period in which he gave attention to freedom of religion, but less understood by the public. Under regime "old order" officially guaranteed, yet communist has performed propaganda to spread their ideology. As a consequence, this regime has occurred political disaster in late 1960 which caused a thousand victims.

According to Sayyid Muhammad Rizvi ${ }^{10}$ the concept of religious pluralism was not new; it has been discussed in one

${ }^{9}$ M.Qurais Shihab, Tafsir Al-Misbah, Published by Pisangan Ciputat:Lentera Hati, 2009, p. 49 
form or another by past philosophers and theologians of various schools. However, with the increased interaction between followers of different religions and inter-faith dialogues, religious pluralism has taken a new life in the stream of current perception. Mukti Ali ${ }^{11}$, other scholar, emphasized the understanding of pluralism can be dealt with two types; partial as well as integral manner. Partial level can be independently stood as teleology and sociology that required interrelation in order to match each other. In integral level can determined as a meeting point among religions and find out religion in same way.

Abdurrahman Wahid highlighted ${ }^{12}$ the social conflict that happened to several regions is none other than is educational mistakes. This miseducating was presumably caused by a strong influence on Fiqh matters. One hand a research of Fiqh matters would easily taught upon different perspective special students who were early introduced the distinction. In the other hand, acknowledge the Oneness of God including social implication actually weren't taught for student except only memorizing of names of Allah Almighty (Asmaul Husna). If it is get into curriculum that may lead to come after a particular school of theology, so than the student get used to dissenting opinion. Thus, that's initially growth a fanatism of religion on unbalanced interpretation.

10 Sayyud Muhamaad Rizvi, Islam and Religious Pluralism, Article, Accessed on 23/10/2016. https://www.alislam.org/islam-and-religious-pluralism-ayatullah-murtadhamutahhari/introduction

${ }^{11}$ Mukti Ali, Religious Comparative Science in Indonesia, UIN Kalijaga Press, Jakarta, 2000, p. 47-49

12 Abdurrahman Wahid, Islamic Thought (Tajuk Rencana), Kompas News Paper 20 Desember 1998, p. 1-3 


\section{Tolerance in Actualizing and Creating Broad- Mindedness}

In Islam Perspective, tolerances can be seen as religious tolerance. Positively, it showing that tolerance has been long time applied either its development or multitude of lesson. This application showed how to respect religion with other religion, Surah Al-Kafirun, article 6 said:

\section{: For you is your religion, and for me is my religion.}

The Surah aforementioned above was addressed to polytheist that obviously not believing in God. In addition, this Surah also contained that Polytheism were purely not to worship Allah Almighty. On the contrary the Muslim who was honestly worshiped except to Allah Almighty.

Indonesia is well known as big Muslim country in the world, but politically, it's not as Islamic religious nation. In contrast, Indonesia has ideology namely Pancasila. Since President Soekarno, the first president, become as the inventor of Pancasila and proposed a Five of principle of secular nationalism who supported by nationalist and Muslim politician. Pancasila, national ideology, was accepted by all of party. In this context would deal with Democratization as stated on the fourth principle of Pancasila. The goal of this principle was educating democratization under a state policy through Member of Parliament. This policy was implicitly expressed by Prophet Muhammad SAW (the body of policy was a wellconsideration).

Burhanuddin Daya ${ }^{13}$, in addition, pointed out that every single religion basically carried out the same message namely moral,

${ }^{13}$ Burhanuddin Daya, Unity of religion Shouldn't Put Away the Value and Commitment Over Religious Universally, Umat Beragama Jangan Lepaskan Komitmen Nilai-nilai Universal Agama, Jogja News Paper, Monday, $6^{\text {th }}$, May, 1996, p. 1 
but different ways. He argued universal values upon all religion would vanish; and event would disappear from religious circulation as result of they were claiming each other. Due to declaring each other, universal values lead to create subjectivities. Accordingly, members of a religious community could keep objectivity of universal value; in such a way that religious matter able to pep up harmonization in political life, social, culture and finally actualized in daily life.

Furthermore, Islam was gracefully religion that affectionately delivery wealthy and prosperity for all mankind were including animals, vegetation and especially human being. In accordance with Surah Al-Ambiya: 107, Allah Almighty saying that;

: And we have not sent you, [O Muhammad], except as a mercy to the worlds.

Islam prohibited going to extreme and arbitrated against God's creatures. Have a look on Prophet Muhammad expression narrated by Iman Al-Hakim. "Whom paradoxically killing birds or other the smallest creatures, than the God asked for his or her responsibility". These birds slaughtered and consumed not killed and threw away. It is here asserted that Islam was truly admirable religion. Any animal should not be abused, let alone humans. Just imagine if societies realize and practice the wisdoms of Islam, it would be really beautiful and the peacefulness of this world.

Nevertheless, it can be concluded that Indonesia was the largest Muslim country in the world. If looking at this expression, Indonesia ought to be a beautiful country, peaceful, and civilized nation. But in contrary, riots, rebellion, anarchism, and terrified demonstration always happened to our beloved country.

\section{CONCLUSION}


This work can be concluded article provision on 29 Indonesian Constitution contained; (a) Believing and god-fearing on Oneness God in accordance with human civilized; (b) Construct the respect and tolerance among religions; (c) Admitting that every citizen free to worship and not to impose the will on other people's religion. This respect is merely to look for and find out the similarity and equality that may have advantages as comparative materials.

The last not least, the tolerance has a value of symbol as follow; (a) Religion is Guidance of God universally, because God sent His messenger to all humanity; (b) Islam is open-minded religion; (c) Islam is appropriate and acceptable religion which receive honor one another; (d) Islam is blessing for human being. The last one, the more high his or her faith is the more high his or her tolerance.

\section{RECOMMENDATION}

- It should well-cooperated among leaders and consistently missionize greatness of God and religion.

- It should open-national dialogue and invited leaders as source of reference through prosper comparative.

- It deservedly for every single either institution or university to form a group of religious study and expectable religious course and sustainable development. 


\section{REFERENCES}

Ali, Muhammad Daud, Islamic Law (Hukum Islam), Publisher

Raja Grafindo Persada, Jakarta, 2001.

Ali, Mukti, Religious Comparative Science in Indonesia, UIN Kalijaga Press, Jakarta, 2000.

Daya, Burhanuddin, Unity of religion shouldn't Put Away the Value and Commitment Over Religious Universally, Umat Beragama Jangan Lepaskan Komitmen

Nilai-nilai Universal Agama, Jogja News Paper, Monday, 6th, May, 1996.

Hasyim, Umar, A Tolerance and Religious Freedom on Islam as a Basic Dialog and Harmony among Religion (Toleransi dan Kemerdekaan Beragama dalam Islam Sebagai Dasar Menuju Dialog dan Kerukunan Antar Agama), Publisher PT. Bina Ilmu, Surabaya, 1979.

Madjid, Nurcholis, Pro-Contra Heading to 1995 (Pro-Kontra Menuju Tahun 1995), Publisher

Paramadina Press, Jakarta, 2005.

Marzuki, Peter Mahmud, Legal Research (Penelitian Hukum), Revised Edition (Edisi Revisi), Cetakan ke-8, Penerbit Kencana Prenada Media Group, Jakarta, 2013.

Shihab, M.Quraish, an Interpretation of Al-Misbah (Tafsir AlMisbah), Publisher Pisangan

Ciputat:Lentera Hati, 2009.

Thohir, Umar Faruq, Discourses of the Rights of Minority of Kafir Drimmi in Muslim Majority, 
(Diskursus Tentang Hak Asasi Minoritas Dzimmi Di Tengah

Mayoritas Muslim), Article, 2002.

Qardlawi, Yusuf, an Islamic Social System in the Koran and Sunnah (Sistem Masyarakat Islam dalam Al-Qur'an \& Sunnah), Published by Pustaka Online Media ISNET, Pakdenono, 2006.

\section{DICTIONARY}

Merriam, Webster's American English Dictionary, Created in Cooperation with the Editors, USA, 2012.

\section{ELECTRONIC MEDIA}

Rizvi, Sayyud Muhamaad, Islam and Religious Pluralism, Article, Accessed on 23/10/2016.

https://www.al-islam.org

Wahid, Abdurrahman, Islamic Thought (an Article of Tajuk Rencana), Kompas News Paper, 20

December 1998. www.kompas.com 